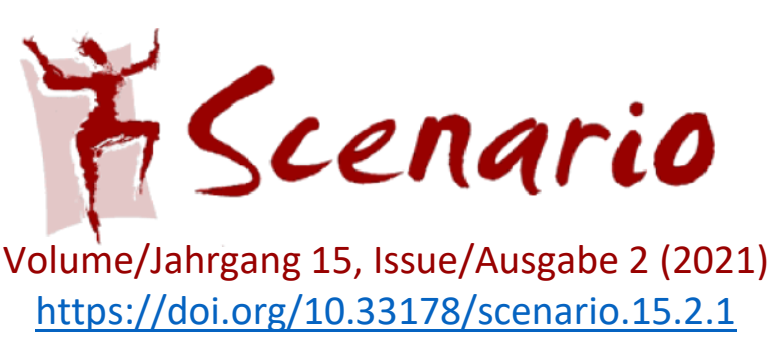

\title{
The double-edged sword of storytelling
}

\section{Performative language pedagogy with refugees, asylum seekers and migrants}

\section{Erika Piazzoli \& Elif Kir Cullen}

This article considers the ethical dimension of performative practice with refugees and migrants, positioning storytelling as a double-edged sword that can either elevate or stigmatise the storyteller. The discussion is inspired by 10 things you need to consider if you are an artist, not of the refugee and asylum seeker community, looking to work with our community, a manifesto written by Cañas, Refugee Survivor and Ex-Detainee (RISE) art director. First, the paper introduces the RISE manifesto and its significance to contemporary practice and research. Second, it discusses relevant literature, looking at the construct of aesthetic distance (Erikson, 2011), safe space as creative space (Hutton, 2008) and aesthetic form as double (Courtney, 1995) in drama. The core of the paper reports the analysis of nine interviews, conducted with professional artists, teachers and practitioners working in the context of forced migration. Data points to the interconnectedness between participants and facilitator, in terms of self-expression, creativity, vulnerability and agency. In this regard, the authors reframe vulnerability as an active, creative, liminal space essential to foster an ethical imagination. This kind of creative vulnerability, key to practitioners' ethical imagination in performative work, can act as a segue into the symbolic, metaphorical mode of drama.

\section{Introduction}

This article of Scenario was inspired by the Refugee Survivor and Ex-Detainee (RISE) manifesto, a list of ten statements written in 2015 by RISE art director Tania Cañas. Each statement in the RISE manifesto is followed by an explanatory paragraph. One of the tenets in the manifesto focuses on the notion of participation as a double-edged sword in storytelling, advancing that "participation is not always progressive or empowering". It is followed by this call:

\footnotetext{
Your project may have elements of participation but know how this can just as easily be limiting, tokenistic and condescending. Your demands on our community sharing our stories may be just as easily disempowering. What frameworks have you already imposed on participation? What power dynamics are you reinforcing with such a framework? What relationships are you creating? (Cañas, 2015, para 5, our emphasis)
}

This statement raises crucial issues in the field of performative language teaching, insofar as participation is a precondition for performative pedagogy to exist. Performative language 
teaching is an umbrella term that describes an orientation to teaching and learning a second language through the performative arts (Schewe, 2020). It is a participatory form, involving a group of people (the teacher as facilitator and students as participants) engaged in a creative process of storytelling. In the last decade, performative work with refugees and asylum seekers has proliferated (Cox \& Wake, 2018). Indeed, since the special issue of the Research in Drama in Education (RiDE) journal on performance and asylum was published in 2008 (Gielbert \& Nield, 2008), several projects have brought renewed rigour to the expectations of ethical conduct in performative work with refugees. Ten years on, the RiDE 2018 special issue on performance and forced migration documented several examples of projects based on a solid ethical foundation (Marschall, 2018; Price, 2018; Hemelryk Donald, 2018).

The RISE manifesto is a key document that informed the authors' performative language practice and research, particularly our project Sorgente: Engaging asylum seekers, refugees and their teachers in performative language pedagogy. The primary goal of Sorgente was to engage young refugees, migrants and their teachers in a cycle of participatory workshops to explore the connections between performative language learning, motivation and belonging. The project took place in Dublin (Ireland) and Padova (Italy) and was funded by the Irish Research Council (IRC). It comprised a team of ten academics, led by the first author as Principal Investigator, in collaboration with two community partners, the Youth and Education Service for Refugees and Migrants, and Youthreach (City of Dublin Education and Training Board) and the international partner of the study, Razzismo Stop, led by Fiona Dalziel, University of Padova, Italy. Acknowledging the importance of the issues raised by the RISE manifesto, in the preparatory phases of the Sorgente study, we conducted a literature review of existing arts-based projects that operate in the context of forced migration, identified nine informants from these projects (experienced teachers, facilitators and artists) and interviewed them. Directly inspired by the RISE manifesto, our aim was to gain the key informants' perspectives on the relationship between practice, power and participation in performative work. The respondents' insights informed our praxis, intended as theory feeding into practice in a self-generative loop (Piazzoli \& Kir, 2020) and contributed to the research design of the Sorgente study.

In this article, rather than discussing the whole Sorgente project (42 hours of performative workshops, across three case studies) we focus on the backdrop of the study: the RISE manifesto, the key informants' interviews and how they shaped the research design. First, we outline the ten points in the RISE manifesto. Second, we frame the manifesto within the literature, considering both theory and research. In the core of the paper, we analyse nine qualitative interviews with professionals, through the lens of the themes raised by the RISE manifesto. We cross-reference the findings with the RISE manifesto and the key respondents' 
findings. Finally, we revisit the notion of vulnerability, agency and creative space, reflecting on how the RISE manifesto functioned as a landmark to inform our praxis, outlined below.

\section{The RISE Manifesto}

RISE is an organisation managed by refugees, survivors and ex-detainees, based in Melbourne, Australia. It was founded in 2009, launched in 2010, and is currently active through support services, education services, advocacy campaigns, initiatives and events to spread awareness of mandatory detention in Australia, and global treatment of refugees. ${ }^{1}$ In 2015, the RISE committee produced a manifesto, penned by Tania Cañas, featuring ten statements addressed at artists interested in working with refugees and asylum seekers.

The manifesto was formulated as a direct response to an influx of artists approaching RISE with a "false sense of neutrality and limited understanding of their own bias, privilege and frameworks" in order to find 'subjects' for arts projects (Cañas, 2015, para 1). In drafting the text, the author addresses the reader directly, conferring an upfront, outspoken tone on the piece. The direct address mode applies to the ten statements, as well as to the title of the manifesto: "10 things you need to consider if you are an artist, not of the refugee and asylum seeker community, looking to work with our community". The political overtone is a leitmotif throughout the text, made explicit in the tenth statement, "art is not neutral". As such, the manifesto can be framed within critical theory (Thompson, 2017; Berman, 2018) as a political text that denounces hegemonic power structures inherent in the Australian society (and by extension, in Western society), advocating for the rights, the voice and the individuality of refugees and asylum seekers. The manifesto is reproduced in full below.

\begin{tabular}{|l|l|}
\hline 1. Process not product & $\begin{array}{l}\text { We are not a resource to feed into your next artistic project. You } \\
\text { may be talented at your particular craft but do not assume that } \\
\text { this automatically translates to an ethical, responsible and self- } \\
\text { determining process. Understand community cultural } \\
\text { development methodology but also understand that it is not a } \\
\text { full-proof methodology. Who and what institutions are } \\
\text { benefiting from the exchange? }\end{array}$ \\
\hline $\begin{array}{l}\text { 2. Critically interrogate } \\
\text { your intention }\end{array}$ & $\begin{array}{l}\text { Our struggle is not an opportunity, or our bodies, a currency, by } \\
\text { which to build your career. Rather than merely focusing on the } \\
\text { other (where do I find refugees? etc.) subject your own } \\
\text { intention to critical, reflexive analysis. What is your motivation }\end{array}$ \\
\hline
\end{tabular}

${ }^{1}$ https://www.riserefugee.org/ 


\begin{tabular}{|c|c|}
\hline & $\begin{array}{l}\text { to work with this particular subject matter? Why at this } \\
\text { particular time? }\end{array}$ \\
\hline $\begin{array}{l}\text { 3. Realise your own } \\
\text { privilege }\end{array}$ & $\begin{array}{l}\text { What biases and intentions, even if you consider these 'good' } \\
\text { intentions, do you carry with you? What social positionality (and } \\
\text { power) do you bring to the space? Know how much space you } \\
\text { take up. Know when to step back. }\end{array}$ \\
\hline $\begin{array}{l}\text { 4. Participation is not } \\
\text { always progressive or } \\
\text { empowering }\end{array}$ & $\begin{array}{l}\text { Your project may have elements of participation but know how } \\
\text { this can just as easily be limiting, tokenistic and condescending. } \\
\text { Your demands on our community sharing our stories may be } \\
\text { just as easily disempowering. What frameworks have you } \\
\text { already imposed on participation? What power dynamics are } \\
\text { you reinforcing with such a framework? What relationships are } \\
\text { you creating (e.g., informant vs expert, enunciated vs } \\
\text { enunciator) }\end{array}$ \\
\hline $\begin{array}{l}\text { 5. Presentation vs } \\
\text { representation }\end{array}$ & Know the $d$ \\
\hline $\begin{array}{l}\text { 6. It is not a safe space } \\
\text { just } \\
\text { you say it is }\end{array}$ & $\begin{array}{l}\text { This requires long term grass-roots work, solidarity and } \\
\text { commitment. }\end{array}$ \\
\hline $\begin{array}{l}\text { 7. Do not expect us to be } \\
\text { grateful }\end{array}$ & $\begin{array}{l}\text { We are not your next interesting arts project. Our community } \\
\text { are not sitting waiting for our struggle to be acknowledged by } \\
\text { your individual consciousness nor highlighted through your art } \\
\text { practice. }\end{array}$ \\
\hline $\begin{array}{l}\text { 8. Do not reduce us to an } \\
\text { issue }\end{array}$ & $\begin{array}{l}\text { We are whole humans with various experiences, knowledge } \\
\text { and skills. We can speak on many things; do not reduce us to } \\
\text { one narrative. }\end{array}$ \\
\hline 9. Do your research & $\begin{array}{l}\text { Know the solidarity work already being done. Know the } \\
\text { nuanced differences between organisations and projects. Just } \\
\text { because we may work with the same community doesn't mean } \\
\text { we work in the same way. }\end{array}$ \\
\hline 10. Art is not neutral & $\begin{array}{l}\text { Our community has been politicised and any art work done } \\
\text { with/by us is inherently political. If you wish to build with our } \\
\text { community know that your artistic practice cannot be neutral. }\end{array}$ \\
\hline
\end{tabular}

Tab. 1: Rise Manifesto (https://www.riserefugee.org/10-things-you-need-to-consider-if-you-are-an-artist-not-of-therefugee-and-asy/um-seeker-community-looking-to-work-with-our-community/) 
In the preparatory phase of the project, on encountering the manifesto, we found it refreshingly provocative. Crucially, we recognised that the manifesto spoke to us directly as practitioners: we were involved in a project with refugees and migrants, featuring elements of participation and claiming to create safe spaces through arts-based strategies. At the onset of the Sorgente project, the manifesto led to a period of self-scrutiny and reflexivity where, echoing RISE statement 2, we critically interrogated our own positionality, biases and understanding of practice.

\section{Literature Overview}

In this section, we review the literature through the lens of three statements from the RISE manifesto. They are, respectively, point 8 ("Do not reduce us to an issue"), point 6 ("It is not a safe space just because you say so") and point 5 ("Presentation versus Representation"). While we have chosen these three statements to organise the sub-headings, we will reference all the statements in the discussion, as they are all relevant to the argument of this paper.

\section{1 'Do not reduce us to an issue'}

I'm sick of telling my story; talk talk talk talk talk. I already told my story. It doesn't work. I don't want to. Don't make me do this. Sorry, I don't want to play. (in Cummings, 2016, p. 161)

The words above were spoken by an asylum seeker, playing the character of a refugee, in Journey of Asylum - Waiting, a piece devised and performed by refugees and asylum seekers, directed by Catherine Simmons in 2010. This play explored the "tensions between agency and vulnerability that accompany acts of telling" (in Cummings, 2016, p. 181). The words of the actor (an asylum seeker, in role as a refugee) voice the frustration in having to narrate her personal story once again in front of an audience - understood not only as audience in the theatre, but also audience in a sociological sense: case workers, administrators, immigration agents, and so forth. The actor recounts how boundaries were crossed, moving from personal into fictional, with her story reduced to one single narrative - the core message of point 8 in the RISE manifesto.

A useful construct to understand the resonance of this argument is that of aesthetic distance which can be understood as the awareness of being in and out of a fictional role. The term was first described by Bullough in 1912 as a principle that marks "one of the most important steps in the process of artistic creation" (1912/2001, p. 3). Distance, for Bullough, is a feature of an aesthetic experience related to a 'filtered' perception of reality. He adds: "The sudden view of things from their reverse, unusually unnoticed, side, comes upon us as a revelation, and such revelations are precisely those of $\operatorname{Art}^{\prime \prime}$ (p. 3). To explain this concept, he uses the 
example of being a passenger on a ship surrounded by fog. This experience, he holds, could be perceived in many different ways according how we relate to the fog itself and its surroundings. We may experience the fog with trepidation, fear, or frustration. Conversely, if we are able to detach from the practical aspect of being stuck in fog at sea and observe it under a new, distanced perspective, we may experience it as a source of relish and enjoyment - or even appreciate a certain poetic quality in its beauty.

Eriksson $(2007,2011,2022)$ has written extensively on the phenomenon of distance in drama education, understood both as an aesthetic principle in art and a pedagogical strategy in the classroom. In this sense, aesthetic distancing is aimed at "safeguarding participants' actions from consequences of 'the real'" (2022, forthcoming). Indeed, as Eriksson suggests, aesthetic distance can act as an obstacle to the automatic acceptance of widespread social narratives or dominant ideologies - a concept particularly relevant to the present discussion.

Having lived through the restrictions imposed by various governments during the COVID-19 pandemic, we are all familiar with the concept of distancing as in 'social distancing' - the amount of (physical) space to be observed between two or more people, to limit contamination. 'Aesthetic distancing' works in a similar way, but figuratively: it is the amount of (metaphorical) space to be observed within oneself and the role(s) being played in the make-believe. An asylum seeker playing the role of a refugee in a play, as in the example reported by Cummings (2016) above, is an instance of limited aesthetic distancing, as the role played by the character in the drama (a refugee) overlaps with the everyday self of the person interpreting the role (an asylum seeker). The very act of telling her story, re-living the experience through storytelling on a stage, was a painful undertaking as it reduced the asylum seeker's identity to one single narrative.

Research has shown that an awareness of distancing in participatory drama influences the experience and intensity of emotions (Bolton, 1984; Dunn, Bundy \& Stinson, 2015, 2020; Piazzoli \& Kennedy, 2014). Like a pendulum, aesthetic distance can oscillate between emotional over-identification (too little aesthetic distance) or emotional detachment (too much distance). Too little aesthetic distance (over-identification) can be problematic, as participants may become too identified with the roles they are playing, re-igniting previous trauma and causing an emotional overload. On the other extreme of the pendulum's swing, too much aesthetic distance (under-identification) can cause disinterest or disengagement with the work. Yet, a reasonable amount of distance helps participants to experience degrees of empathy, a key to all make-believe.

If managed competently, aesthetic distancing as a poetic device can help conjure up the multiple narratives in a participant's experiences of life, by inspiring future possibilities. Dunn 
et al. (2019) conducted a multiple case study, Y Connect, using arts-based pedagogy in a secondary school with $51 \%$ of the population from refugee and asylum seeker backgrounds. They report that through an arts-based intervention, including process drama, their participants were able to connect more meaningfully to their selves, to each other, to learning, to a sense of belonging in the community, the arts and their future (Dunn et al., 2020, xv). They add:

\begin{abstract}
Through deep involvement in arts projects and multiple chances to engage with artists and arts organisations, $\mathrm{Y}$ Connect supported its young participants to broaden their pathway aspirations, whilst also helping them to develop the confidence and drive to pursue these re-imagined futures. Given that possible selves emerge through awareness and direct "lived" engagement, the $Y$ Connect Project was critical as a vehicle for identifying and exploring options that might otherwise have been outside their realm of experience. (2020, p. 171)
\end{abstract}

Using arts-based pedagogy, storytelling and drama can either open up possibilities and provide inspiration, like Dunn et al. point out above, or stigmatise individuals into predefined narratives, as denounced by the character in Simmonds' Journey of Asylum - Waiting. In this sense, we recognise that storytelling can be a double-edged sword in performative language practice with refugees and asylum seekers: it can empower and inspire, or belittle and nullify.

Smith reinforces this point. The founder of Creative English, a programme that has brought drama to over 10,000 refugees asylum seekers and migrants. She writes:

Lots of us are curious about refugees' experiences. None of us are defined by any one experience. In the experience of being granted asylum, refugees will have to tell their story over and over again and the more traumatic it is, the more likely they are to be given leave to remain. No one wants to be defined as a victim. It's best therefore not to ask people about how they got here or why they had to leave. Focussing on the present and the skills and interests of a person is much more constructive. (Smith, 2016)

Smith acknowledges that avoiding pre-arrival stories when working through the creative medium of drama particularly important, as refugees tend to be "constantly prescribed the role of victim by both society and the way they are represented in art" (2016b, p. 10). This is a vital point because, as statement 10 in the RISE manifesto reminds us, art is never neutral, and all arts-based practice is inherently political. 


\section{2 'It is not a safe space just because you say it is'}

As the RISE manifesto denounces, establishing a 'safe space' is not a given. Redmond (2010) advances the notion of 'safe space' as chimera, a goal towards which educators strive, but never fully attain. Arguably, space is neither safe or unsafe; it is the practices implemented which can be inclusive or exclusive, making participants feel threatened or supported. According to Kenney (2001), the expression safe space was first used in the mid-1960s by the queer activist community and was later adopted in the 1970s by women's movements. As Hunter (2008) notes, while the phrasing was initially associated with feminist literature (Ardener, 1993), in the last two decades it has become common currency in educational discourse. Boost Rom (1998) reflects on the metaphor of 'safe space' in education noting that, although the phrasing is used frequently, it is seldom deconstructed. He refers to freedom of speech and respect:

In a 'safe space', people are encouraged to speak their minds freely and to share their experiences openly, and they are guaranteed that their expressions of self will be as well regarded as anyone else's. (1998, p. 407)

He points to the absence of stress, threat and criticism, but warns that safe space should not censor critical thinking. Hunter (2008) investigates the nature of 'safe space' in performance, pointing to a link between safe space and risk-taking. This, as we will argue below, also relates to vulnerability - both in the facilitator and participants. Hunter $(2008$, p. 8) defines safe space on four levels, from concrete to abstract:

- A space offering physical safety. The material qualities of a given space (a room, a studio, a hall) that shelters and protects the human body from danger.

- A space offering metaphorical safety. A space "bordered by temporal dimensions" (like a workshop, or rehearsals that begin and end at a given time) during which discrimination and intolerance is barred.

- A familiar space. Safe space is where people are comfortable with each other; where practices are known, and relationships are familiar. In Hunter's words, in this sense "the space becomes safe as it becomes known."

- A creative space. Safe space is conceptualised through the rules of creativity and innovation, where one is free to create without shaming. It is this space that invites a greater degree of aesthetic risk, "a product of the dynamic tension between known (safe) processes and unknown (risky) outcomes."

Hutton believes that the common thread in the four categories of safe space is risk-taking. The more individuals feel safe (physically and metaphorically), the more they will feel ready to shed defensiveness and be creative - in other words, to take the risk of exposing themselves in the creative process. 
White and Lorenzi (2016) investigate creativity in education and propose a multidimensional model of creative space. They initially reviewed other scholars' conceptualisations of creative space (Bocconi et al., 2012; Jankowska \& Atlay, 2008; Davies et al., 2013) and generated a framework, which they then used to analyse questionnaires and fieldwork. Their research is based on data collected at Fighting Words, a creative writing organisation that first opened in Dublin in 2009. The centre's practice involves students creating characters and developing dialogue in response to scenario-based role plays, and interpreting their stories in groups. They describe space as a metaphor for creativity:

\section{Space is a concept which lends itself to be read not only in physical but also in metaphorical terms. It encompasses physical architecture/surroundings, climate, atmosphere, attitudes, relations and experiences. In our view, the term creative space therefore best captures the multidimensionality of creativity. (2016, p. 774, original emphasis)}

In their model of creative space, White and Lorenzi (2016) identify three interconnected dimensions: physical, social-emotional and critical. Each dimension is characterised by the space being open, light, dynamic, stimulating, unexpected, and cosy. They use these terms (which emerged from questionnaires and fieldwork data) as a structure to analyse the creative spaces created through their practice in the Fighting Words centre.

In the context of forced migration, establishing a safe, creative space is connected to Hutton's (2008) four levels, and White and Lorenzi's (2016) dimensions, but must also be understood through the theory of aesthetic distancing (Bullough, 1912/2001; Eriksson, 2002, 2011, 2022). Of particular relevance here is the idea of distancing as protection, what has been described as 'protecting participants into emotion' (Bolton, 1984; Dunn, Bundy \& Stinson, 2015; Eriksson, 2022). The facilitator is responsible for choosing the appropriate creative impulse, one that can stimulate and engage, yet avoids under-distanced experiences that could emotionally overload the group, re-igniting previous trauma. In the context of performative work with refugees, this translates into choosing the right kind of story.

Balfour, Burton, Dunn and Woodrow (2015) conducted a qualitative research project using an arts-based pedagogy, including process drama, to engage refugees, asylum seekers and migrants, in partnership with MultiLink Community Services, a refugee support agency. While discussing the strategies used in the practice, they aimed for "avoiding pre-arrival stories"; instead, they chose to use stories that could "offer an appropriate level of distancing and emotional protection through symbol and metaphor" (2015, p. 5). Working with pre-arrival stories is likely to reaffirm trauma or evoke suffering by re-living the past, what Jeffers (2008) has defined as perpetuating "narratives of victimhood" (p. 218). Thus, we argue that an awareness of distancing as an aesthetic device affects the fragile dynamics of safe spaces. 
Balfour et al. put forth a series of guiding principles which informed every aspect of their practice. The third principle on their list is: "Trauma stories or approaches that adopt deficit models need to be resisted" (p. 74). They add that their goal was to reject deficit perspectives, positioning their participants as "capable and competent learners." (p. 75). As they state in the introduction: "We are keenly aware that our attempts may conceal and congeal important narratives, and in this context in particular, risk reproducing powerlessness inside the representational scheme of research and practice" (2015, p. xiv). Reproducing powerlessness, as the authors put it, is not only unproductive in terms of learning and engagement; it is unethical.

\section{3 'Presentation versus representation'}

Performance affords the possibility to explore the 'as if' mode through metaphor and symbol. This echoes the fifth point in the RISE manifesto, "presentation versus representation", a statement followed by the bid: "know the difference!". Though this may appear like a simple statement, it is by no means simple to explain.

Drawing on Wittgenstein (1953/2010), Courtney $(1995$, p. 90) argues that the key to grasping the difference between presentation and representation is taking a leap from the mode of direct experience ('I see this') to a first level of abstraction, that is, the mode of imagination ('I see this as...') to a second level of abstraction, the mode of dramatic action (seeing 'as if...'), leaping from 'seeing as' to 'seeing as if , in what Courtney calls "the double in aesthetic form" (1995, p. 57).

Returning to storytelling and forced migration, we argued above, with Balfour et al. (2015), that using pre-arrival stories with refugees and asylum seekers is likely to re-ignite trauma and should be avoided, and fictional stories should be favoured. This is more nuanced than it seems. While individuals are engaged in a fictional story, there may be resonance to their lived experience. This is what makes drama unique, the overlap of personal felt-experience filtered through the fictional plane:

\section{'Drama' is a spontaneous human process whereby we think and act in an 'as if' fiction while, simultaneously, we are engaged in the living process. Theatre codifies into art form the kinds of feelings created in all human spontaneous and dramatic acts. However, this happens in varying degrees between the most absorbed and the most distanced (Courtney, 1995, p. 3)}

Courtney elucidates the difference between presentation and representation when he states, above, that theatre codifies feelings into art form. In the final line, he hints at the pivotal role 
of aesthetic distance. Through aesthetic distancing, drama can afford the possibility to work with stories on a symbolic, rather than direct mode of experience.

Campbell and Hogan (2019) describe the same concept when they refer to distancing through the imagination:

Stories, when shaped into effective pretexts, provide a certain type of distancing and through imagination and creative responses allow for spaces to play, away from the traumatic issues the participants may have faced in the everyday world. (p. 47)

However, in multicultural contexts, distancing must be infused with intercultural tact. Campbell and Hogan discuss an incident in their process drama practice that highlighted the importance of being flexible and ready to adapt. The authors are part of Connected, a programme established in 2016 by Sydney Theatre Company, which uses drama to strengthen refugees and asylum seekers' English communication skills. In one of the process dramas they facilitated, Campbell and Hogan (2019) chose the myth of Pandora's box as pre-text, assuming that students would be familiar with Greek mythology. However, some participants were uncomfortable with the concept of Zeus as a god, prompting the facilitators to realise that they were coming from a Western perspective in their repertoire. As a result, they adapted the myth of Pandora's box, keeping the main elements, but removing some connotations, obtaining what they describe as a process of "playful liberation" (p. 45). This is another aspect related to storytelling in multicultural contexts, one which we were interested to investigate.

To explore the issues of ethics, practice and storytelling with refugees and migrants in more depth, we interviewed nine practitioners, six from the field of arts-based performative practice, and three teachers from our community partner CDETB.

\section{Key Informants' interviews}

The nine qualitative interviews presented below were semi-structured and lasted about 30 minutes each. All interviews were audio-recorded and transcribed. The data was analysed using NVIVO 12 software, in a process that involved: sifting through raw data and coding to create the coding tree structure; identifying emerging themes with the NVIVO annotation tool; and visualising the connections between themes through the NVIVO mind-mapping function. In this paper, we focus on one interview question, related to point 4 of the manifesto: Do you believe practice always empowers or can it also disempower?

Some of the interviewees gave consent for their real name to be displayed, while others elected to remain anonymous. Interviewees came from a variety of contexts: Maeve Stones from Change of Address, a collective of artists based in Dublin; Anne Smith, founder of Creative 
English (UK); Orla Lehane from Fighting Words (Dublin); Ailbhe Kenny, Music Educator (Mary Immaculate College, Limerick); Rachel Hoare, second language teacher and play therapist (Trinity College Dublin); and David, Ben and Moira, teachers from City of Dublin Education and Training Board (CDETB). As the interviewees are language teachers, directors, artists, facilitators, as well as applied theatre, drama, music-making, creative writing and play therapy practitioners, for the sake of clarity we refer to the respondents as 'teacherartists/facilitators', albeit some may be teachers, others may be artists, facilitators, or both. The interviews were granted ethical approval by the School of Education, Trinity College Dublin.

All interviewees acknowledged that, when working with refugees and asylum seekers, storytelling acts a double-edged sword, as it should empower but, in truth, it can also disempower. One respondent openly questioned whether empowerment/disempowerment should be considered as a binary and rejected that idea as simplistic. We endorsed this point and used it as a lens to sift through the respondents' answers. By reviewing the data in this light, we concluded that power relationships are influenced by a matrix of several factors. These influence, and are influenced by, not only the students/participants, but also by the teacher-artist/facilitator. More than that, respondents' answers pointed to the interconnected relationship between the facilitator and the student/participants' empowerment.

For example, Maeve Stones, from Change of Address, reflected that, whenever as facilitator she felt she was not able to support the group, she had become disempowered to the point of feeling "complete helplessness":

If the practice is an engagement with people who are bringing either traumatic or difficult experiences into the room and there is an inherent power dynamic that you have to acknowledge as a facilitator. And I think in moments where that isn't handled properly, or your own skills fall short of being able to support the person, or their experiences and thoughts, where it can ... become disempowering, I suppose, for a person that you're working with. Or equally for you, as a theatre-maker, because ... it's a moment of feeling complete helplessness, you know, where - where you're confronted with ... a moment or a person that you should be able to hold in ... a safe place, in what you're asking from them is suddenly not in a safe place. (M.S., p. 2:38-45, our emphasis)

This passage speaks directly to statement 6 in the RISE manifesto, connecting the idea of safe space (or lack thereof) and helplessness. Indeed, Stones is well aware of the RISE manifesto, 
as it appears in full on the Change of Address website ${ }^{2}$. Stones' high level of reflexivity is particularly insightful as it allowed us to consider the construct of 'vulnerability' in its multifaceted essence. In the extract above, she equates her experience of 'vulnerability' as complete helplessness; initially, then, it would appear to be construed as a 'lack of power'.

However, Stones speaks of having learnt from these situations. In the interview she strongly conveys that such practice-based experiences have taught her a lot. Stones denotes that her initial unawareness, linked to vulnerability (helplessness) above, was a point of departure for a learning curve that empowered her to actively face future challenges. Thus, the act of 'making oneself vulnerable' appears to be necessary to learn to operate in that context. As Butler (2014) argues, we ought to "think vulnerability and agency together" (p. 108, original emphasis). Indeed, vulnerability can be construed as a passive or constructive experience. Vulnerability, in this sense, can be construed as a pre-requisite for acquiring a sense of agency in the facilitator's reflective practice.

This is by no means a clear-cut matter. Rachel Hoare's testimony is inspiring here. When working with Sam, a young refugee who stopped going to her arts sessions, she interpreted his disengagement with her practice as 'her own fault' and became discouraged by it. In hindsight, she reflected that, in that particular case, she may have unwittingly "chosen to disempower herself", as certainly it was up to Sam whether to attend or not. Here what emerges is as a complex psychological matrix, with subconscious motifs playing a part in the teacher/facilitator self-regulating her response between vulnerability and agency.

Another theme that emerged from the data is the teacher-artist/facilitator's hidden agenda in wanting to become involved with refugees to quench a desire to 'rescue' people. If the teacher/facilitator frames refugees as 'people that are helpless' and need to be rescued, and if their own hidden agenda is to gain power from this, participants may become disempowered. Here 'disempowerment' may be attributed to what has become known as the white knight syndrome (Lamia \& Krieger, 2009): an urge to rescue other people. Through the Creative English association, Smith trains hundreds of volunteers to become drama facilitators. She is well positioned, then, to observe patterns related to what draws people to become involved in the work as teachers/facilitators. In the interview, she comments:

I think sometimes that's quite hard for people to negotiate because we all want to feel needed. I think sometimes that gets quite wrapped up with people's own sense of identity - the fact that they [facilitators] are happy that they are rescuing people in some way (A.S., p.3: 48-51)

\footnotetext{
${ }^{2}$ http://changeofaddresscollective.com/about
} 
This explanation recalls point 3 in the RISE manifesto, particularly the prompt: "What biases and intentions, even if you consider these 'good' intentions, do you carry with you?".

On a slightly different note, but still related to biases and intentions, one of the interviewees (who chose to remain anonymous) observed that disempowerment in language education settings can be perpetrated, at times, by insisting on using English when participants would prefer to use their own language in communicative exchanges:

So, we've got this tension going on, and sometimes I feel that we disempower them by pushing it a little bit [...]: 'OK, we're going to try one phrase in English today' and I feel that sometimes... that when we push, we're taking their power away. (p.5: 7-11)

This is a controversial issue. It resumes the debate on the hegemony of the English language, with minority languages having less status and power. The interviewee, an experienced facilitator in the field of performative language practice with refugees, is able to sense this tension and to act accordingly in valuing the minority languages of all participants. One simple strategy to achieve that, she explained, was through the creation of multi-language activities that include not only English, but the language of the participants.

Ailbhe Kenny, music education lecturer at Mary Immaculate College, focused on the teacher's choice of repertoire as a key to practice being empowering or disempowering:

\begin{abstract}
Creativity, there can be great empowerment in that. But of course, I'm not so naïve as to think that of course, my practice could also exclude [...] For example, you could end up excluding somebody in your practice, and simply because of your choice repertoire. Simply because of the choice of even musical genre that maybe someone has - has a dislike to; it could be for cultural reasons ... or for religious reasons. (A.K., 2:8-16)
\end{abstract}

Kenny's criticality links curriculum/repertoire choices to inclusion/exclusion. Inclusivity, though, is connected to creating a sense of belonging (or not belonging):

Your practice also has the power to, as you say, disempower. If it ends up excluding people, or if people feel very uncomfortable - uncomfortable to the point that's not creative. That's ... that's actually ... they reject it. Or they feel isolated or that they feel they don't belong to the group. (A.K.2:16-21)

Kenny is an arts education researcher and music educator who worked with children living in Direct Provision ${ }^{3}$ through the Music at the Margins project. Her research draws on

\footnotetext{
${ }^{3}$ Direct Provision refers to the Irish system of accommodation, food and medical services made available to asylum seekers while their international protection application is processed. It is a highly controversial for-profit system, established in 1999 as a temporary measure and is planned to end in 2024.
} 
Piazzoli \& Kir Cullen: The double-edged sword of storytelling

participatory methods, pointing to the importance of the contexts of music-making, as well as children's values, identity and cultural background. In her study, Kenny (2018) argued that bringing together asylum seekers through music enabled storytelling, self-expression and movement.

Orla Lehane, from the creative writing centre Fighting Words, linked empowerment to having a voice, freedom and self-expression:

I think the way we work because it's a space where people come in and it's really about meeting them. So, no-one, no-one has to do this; or no one has to do that. [...] At the heart it's about giving everyone the idea that everyone has a voice. And everyone has something to say and everyone should have the space and the freedom to say that. And so yes it empowers. (O.L., p.5-6: 48-3)

Lehane connected empowerment with participants being able to self-direct, being inclusive, and being free to attend the session without having any external obligations.

Another emerging trend, common to the respondents, was that empowerment and disempowerment are related to the facilitator's teaching style: adopting a didactic ${ }^{4}$ teaching style can be experienced as patronising, hence disempowering, for the students. On the other hand, encouraging autonomy in the classroom was seen as leading to empowering practice, with learner autonomy defined as "the feeling of being the agent of one's own actions" (van Lier, 2007, p. 48).

Stereotyping was also identified by all interviewees as disempowering. Stereotypes may be useful, on one level, to quickly access or make sense of a situation. However, as RISE statement 8 reminds us, narratives that are oversimplified, fixed and tend to cluster into categories can reduce individuals to an issue.

To sum up, the respondents identified behaviours that could disempower such as:

\footnotetext{
${ }^{4}$ In English, the adjective 'didactic' can be used with a negative connotation, as a synonym of instructional.
} 


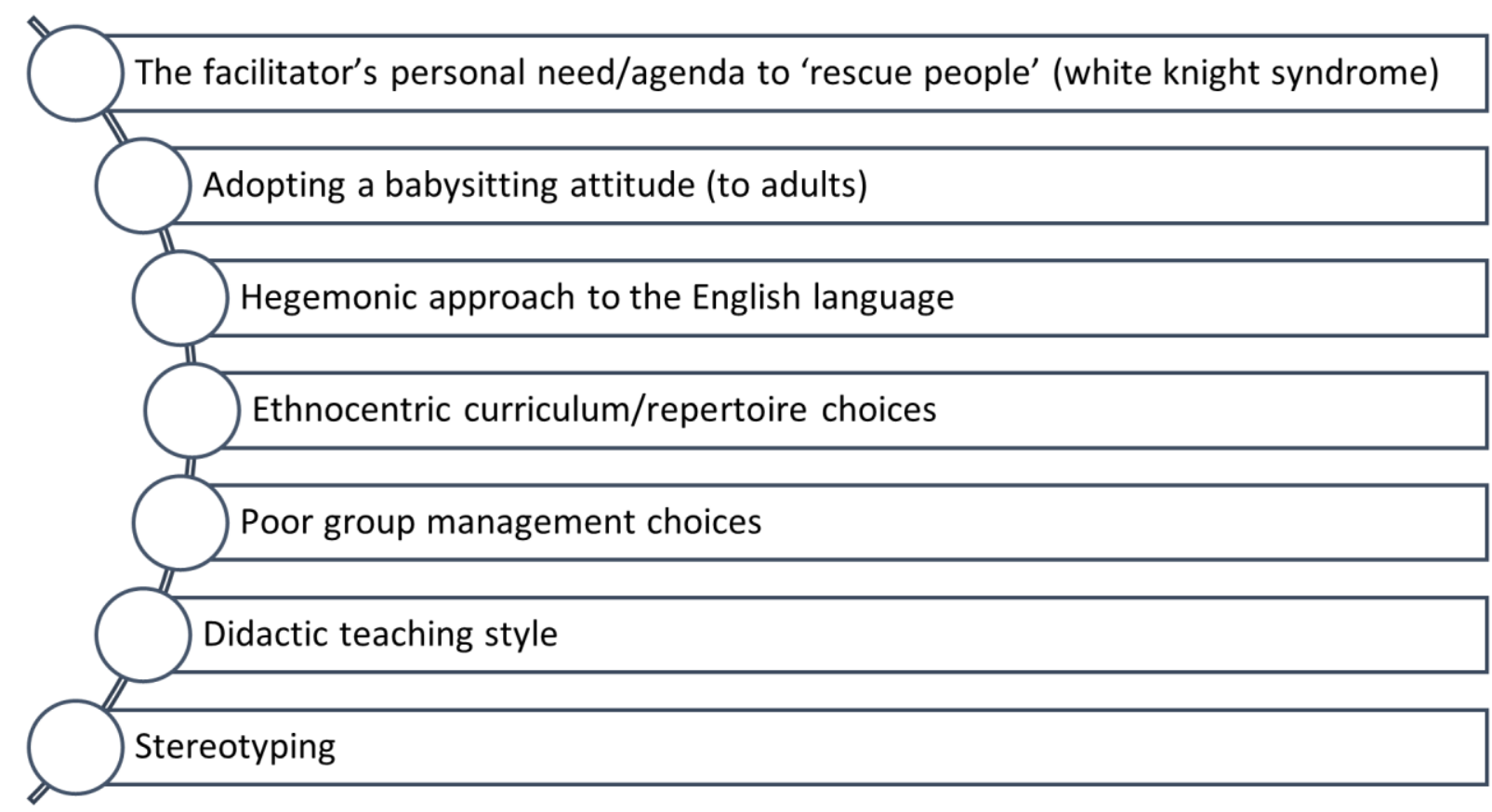

Figure 1: Key informant's perceptions of disempowering behaviours in performative work.

Conversely, the behaviours identified as empowering by the key informants were:

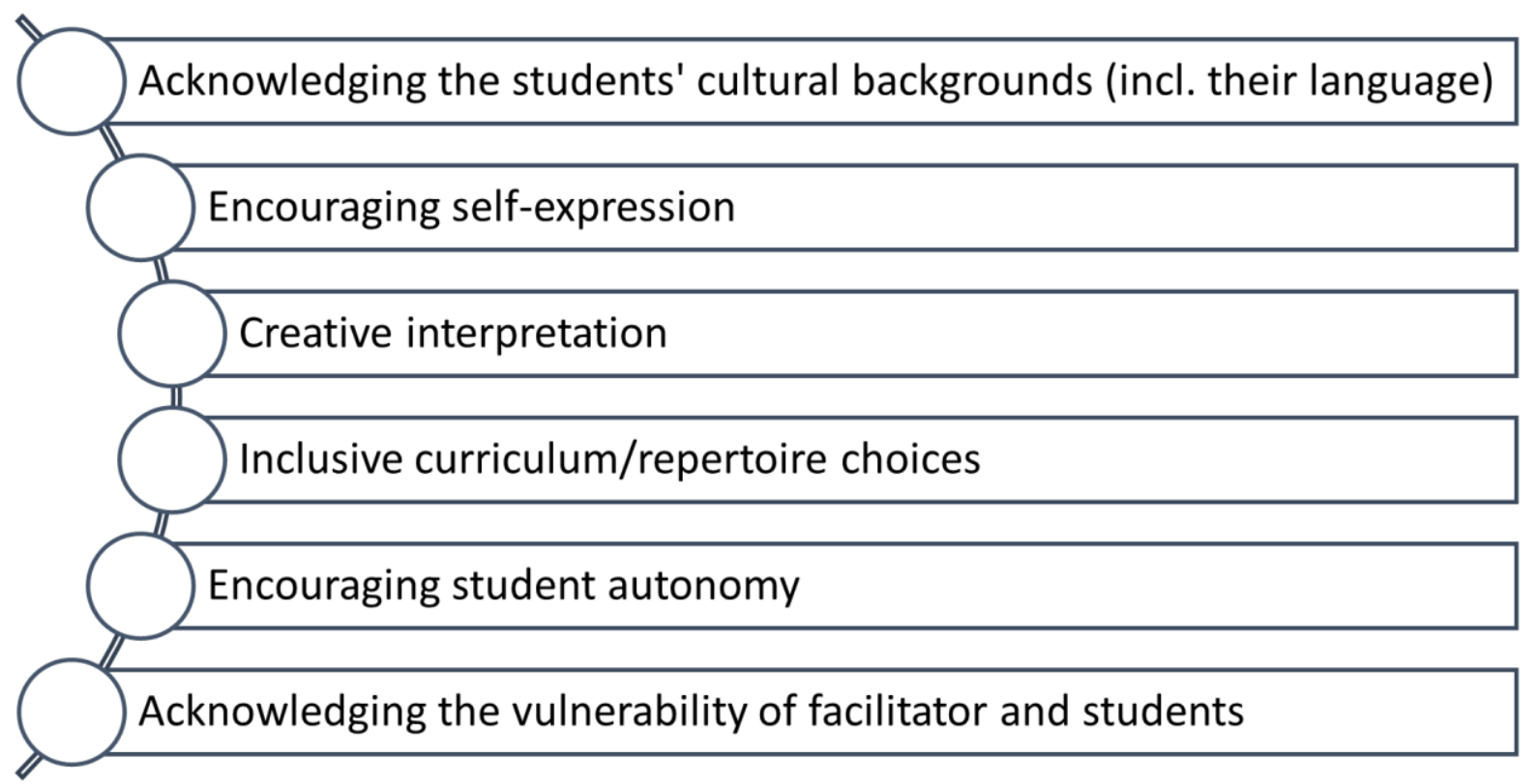

Figure 2: Key informant's perceptions of empowering behaviours in performative work.

In closing, interviewees' perceptions seem to align with RISE's argument that storytelling in performative language practice is not always empowering; it can just as easily be disempowering. If that is the case, how could we balance ethics and imagination, in practice? At this stage, the cycle of theory, reflection and practice takes us to the notion of ethical imagination. 


\section{Discussion}

The phrase 'ethical imagination' was first used by Heathcote (1993), theorised by Edminston (1998) and more recently redeveloped by Hatton (2022). In his essay Ethical Imagination: Choosing an Ethical Self in Drama, Edminston refers to an ethical responsibility and commitment to "build and maintain relationships between students and teachers in an atmosphere of care toward others and the world, which is engaging yet safe, demanding yet fair, challenging yet respectful" (1998, p. 56). As he notes: "As teachers, our ethical principles shape both what we value or encourage as well as what we question or disallow in daily classroom interactions" (p. 57). Hatton (2022, forthcoming) refers to ethical imagination as the reverberation of drama work on participants' sense of empathy, care and responsibility.

Our understanding of ethical imagination builds on the seminal literature (Heathcote, 1993; Edminston, 1998; Hatton, 2022), as well as the ethos of the RISE manifesto. In light of the analysis of key informants' responses outlined above, we are interested in the concept of ethical imagination in the context of performative language practice. To consider this dimension, we return to the focus of the paper, the RISE manifesto and contemplate the key informant responses with relevance to second/additional language education. For the sake of continuity, we structure the discussion using the three points in the RISE manifesto presented earlier in this paper.

\section{1 'Do not reduce us to one issue'}

Statement 8 of the RISE manifesto denounced the tendency of adopting a narrow vision that reduces people that have been displaced to 'one narrative'. Some of the strategies emerging in the key respondents' interviews that we see as conducive to avoid reducing participants to one single narrative are: acknowledging the students' background, knowledge and cultural resources (including their language), and adopting an inclusive curriculum. 


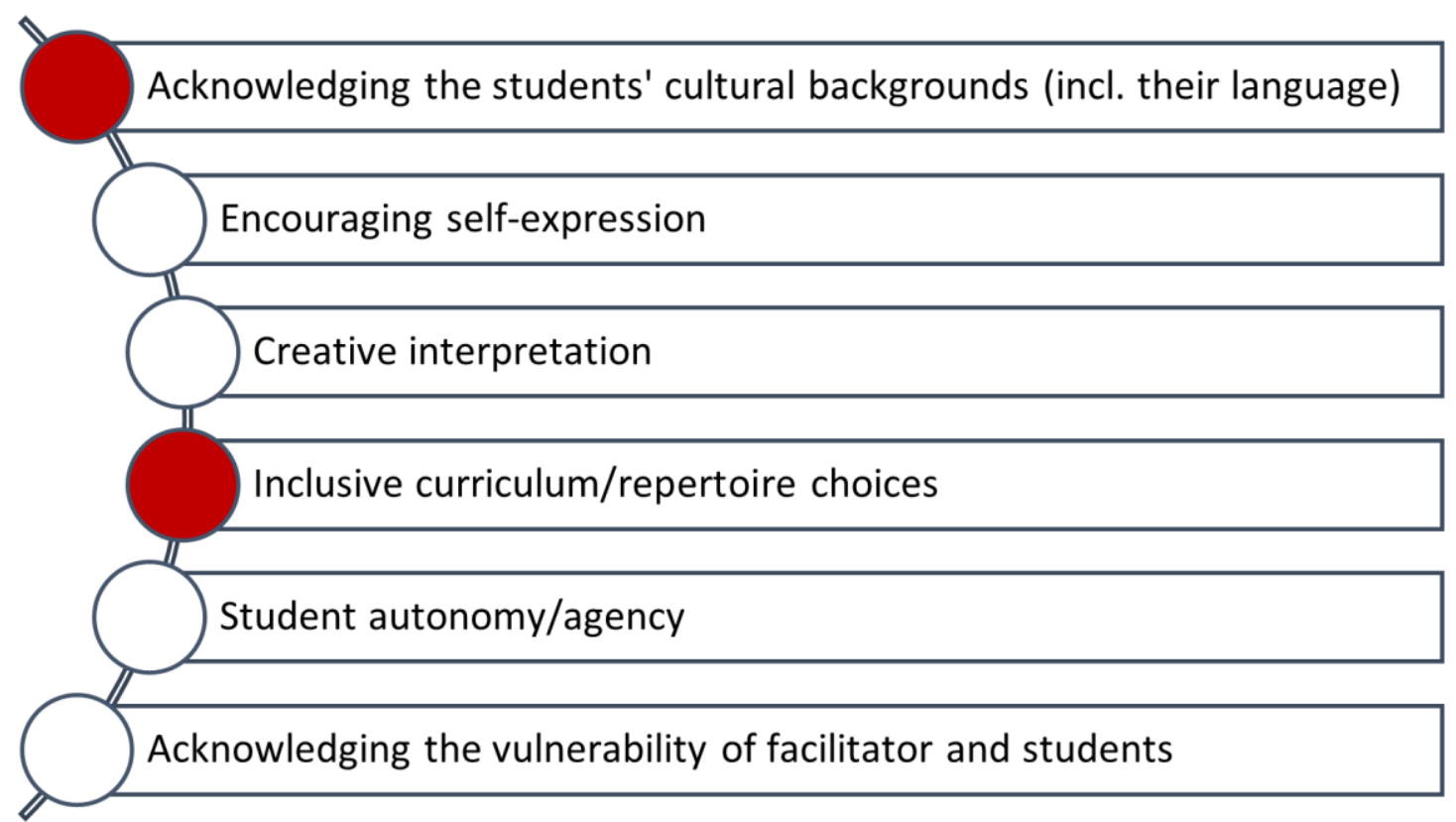

Figure 3: Empowering strategies emerging from the teacher-artists/facilitators' interviews that align with RISE statement 8 , "Do not reduce us to an issue".

Above we discussed the theory of aesthetic distance in storytelling as a device to avoid reducing students' stories to one narrative. To steer clear from under-distancing, stories used can be distanced by time (set in the past or in the future), distanced by space (set in another country, in a faraway land, or on another planet) and/or distanced by a dramatic frame (involving a situation that is different from reality, yet taps into a universal aspect of the human experience). This connects what Campbell and Hogan (2019) describe as the archetypal, universal quality in storytelling when using myths or legends to work with students from refugee and asylum seeker backgrounds:

There is something in the archetypal quality of these tales, classical and traditional folktales, myths and legends tend to have a universal quality, which is really what we are hinting at here, the universality of theme and character that stimulate the imagination; that people no matter where they are from in the world can resonate with. (p. 44)

The degree of aesthetic distance afforded by the metaphorical value of myths and legends feeds aesthetic, symbolic modes of self-expression in the performative mode. Reflecting on the impact of drama on participants' second/additional language learning in the Connected project, Campbell and Hogan (2019) agree that drama can increase confidence to speak in a second language - a tenet that goes hand in hand with learners feeling safe, heard and empowered.

\section{2 'It is not a safe space just because you say so'}


Statement 6 of the RISE manifesto highlights the fragile, elusive nature of safe spaces - an occurrence that can only be accomplished if certain conditions are present. Above, we identified, with Hutton (2008), the physical, metaphorical, familiar and creative qualities of a space that feels 'safe'. The points highlighted in Image 4 certainly contribute to building a safe spaces. However, in this section we focus on two further key respondents' insights (Image 5) that we see as conducive to create the conditions for space to be safe. These are: encouraging student autonomy (agency) and acknowledging the vulnerability of facilitator and students.

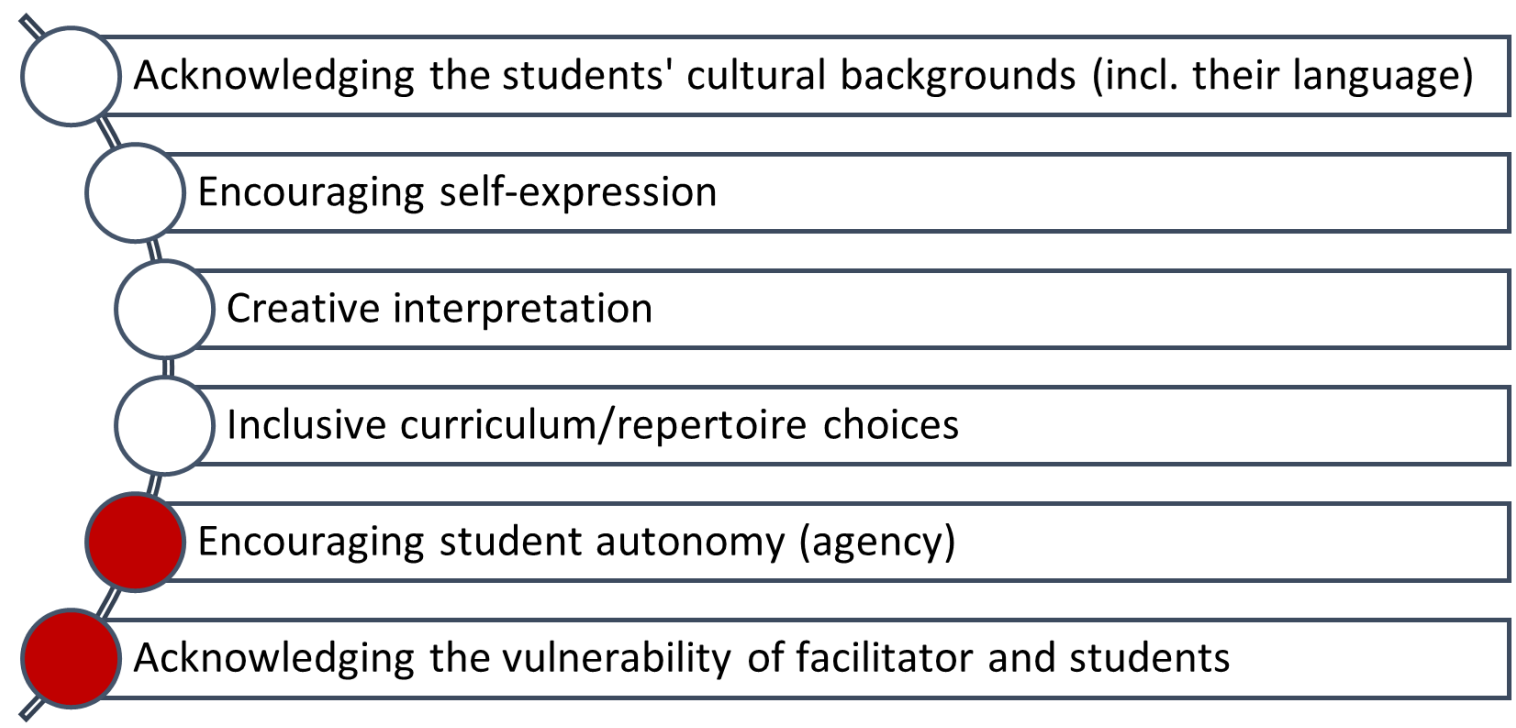

Figure 4: Empowering strategies emerging from the teacher-artists/facilitators' interviews that align with RISE statement 6, "It is not a safe space just because you say so".

In a research study aimed at understanding the effects of drama on second language acquisition, Dalziel and Piazzoli (2019) found that, when conducting a process drama with refugees, the teacher's vulnerability acted as a catalyst to encourage students' agency. As they put it: "The performative frame was able to position us [as Teacher-in-Role] as vulnerable and our students as active agents" (p. 23). It follows that the power differential can spin both ways, with vulnerability and agency being experienced by both the teacher/facilitator and the students/participants.

We propose to frame the facilitator's vulnerability as an active choice, as part of the teacher's ethical responsibility in the drama: the act of 'making oneself vulnerable' to the group, lowering one's defensiveness or perceived status as the sole gatekeeper of knowledge. The key to this transition, we argue, is trust, in its various forms: trust in each other, in the facilitator, in the group dynamics and in the dramatic form. Reflecting on the ethical imagination, Edminston (1998) accepts that through his actions he exercises an ethical responsibility to either "extend or strengthen, or shrink and weaker, the circles of care and connection that form with and among students" (p. 56, our emphasis). By circles of care, he 
refers to the community of practice generated when students' imaginations are harnessed together, a concept akin to Hutton's (2008) conception of safe space as creative space.

With reference to second/additional language learning, we frame safe spaces as hubs where participants feel safe to make a mistake in a second language without feeling shamed or ridiculed. Resuming Hutton's (2008) idea of creative spaces and risk-taking, second/additional language learners take a risk by speaking in another language: the safer the environment is perceived, the higher the risk they may take in their communicative efforts. This is supported by ample evidence on motivation to communicate and the use of drama - a focus thoroughly examined by the Scenario research community (Bora, 2019; Best et al., 2020; Hietz, 2021).

\section{3 'Presentation versus representation'}

Statement 5 of the RISE manifesto flags the fundamental difference between presentation versus representation in art. This key point is what distinguishes a 'cookie-cutter' performance from meaningful dramatic exploration. The examples discussed in 5.1 and 5.2 are relevant to this discussion. Building from those, here, we concentrate specifically on the notions of encouraging self-expression and creative interpretation in language learning.

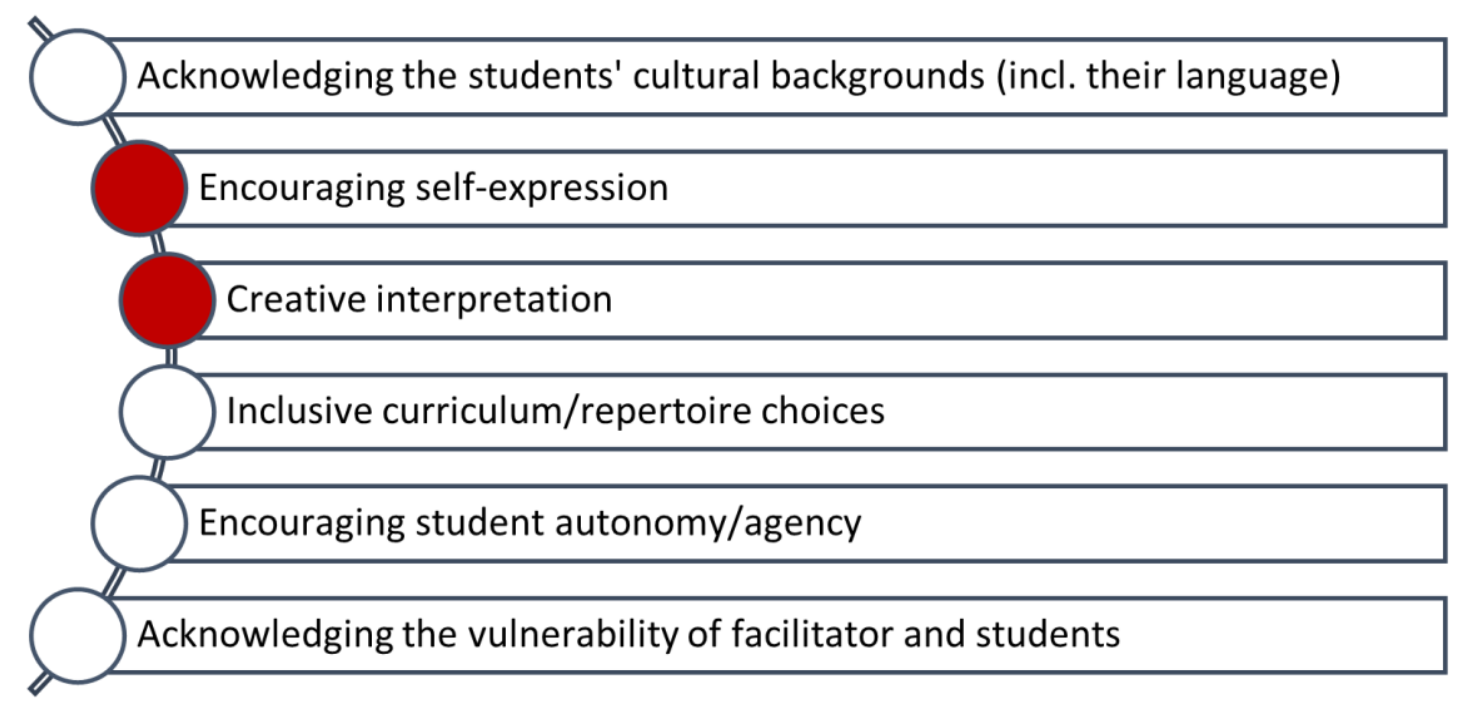

Figure 5: Empowering strategies emerging from the teacher-artists/facilitators' interviews that align with RISE statement 5, "presentation versus representation".

Encouraging self-expression and creative interpretation, the two points emerging from the key respondents' interviews, are pivotal to break free of the cookie-cutter role-play style, common in second/additional language teaching, where little or no attention is given to the symbolic, metaphorical value of drama. In a seminal essay, Bolton (1979) argues: "Drama is metaphor. Its meaning lies not in the actual context nor in the fictitious one, but in the dialectic set up between the two" (p. 128). Playfully manipulating between these two modes comes down to an understanding of form: 
Raw emotion belongs to the actual situation; harnessed, tempered or filtered emotion springs from a dialectic set up between the actual and the fictitious context. Form is made up of the elements that promote and control that interaction: concreteness/abstraction, a sense of time, a sense of significance, contrast and tension. The resulting experience for the participant must be one of heightened self-awareness. (Bolton, 1979, p. 111)

With this statement, Bolton points to the importance of engaging students at an aesthetic level to heighten self-awareness.

Although Bolton was not talking about second/additional learners, here we propose this connection, advancing the possibility that performative language work engages students in a playful manipulation of dramatic form, resulting in heightened awareness (Piazzoli, 2018). Experienced through this mode, even participants at a low language proficiency may explore the universality of a theme - provided, as we have seen in 5.2, there is a degree of trust in the form, in the teacher and in the group.

Once the group comes to trust each other, the facilitator, the group dynamics and the dramatic form - that is, once safe space has been established, the group can aspire to what Hutton (2008) defines as safe space as creative space. In this process, facilitators and students make themselves vulnerable to the process of creation: it is here that the facilitator has an ethical duty to handle this creative vulnerability with care - striving to attain the chimera of 'circles of care' (Edminston, 1998). Hence, we close the circle, arriving back at the idea of ethical imagination.

\section{Conclusion}

The RISE manifesto has been a source of inspiration for us since the genesis of the Sorgente project. In this provocative text, artists and practitioners are urged to consider the ethical repercussions of their work. Before going ahead with the fieldwork in the Sorgente project, we reached out to fellow professionals in the field to gather their views on the topic of practice, power and participation. Data from the key informant interviews pointed to the interconnectedness between the participants and the facilitator, in terms of vulnerability and agency. We noted that vulnerability, in this sense, is experienced by the teacher/facilitator, too - and that this may be necessary for the establishment of a safe space, intended as a creative space (Hutton, 2008). In this regard, we advanced that it is useful to consider vulnerability as not only passive, but also active; a creative, liminal space essential to foster an ethical imagination. 
Probing deeper, we wondered how to strike a balance between ethics and the imagination. The participatory quality of performative practice is what makes it unique as an art form, as the facilitator is working with individuals who congregate in a physical space, for a set amount of time, to play in the 'seeing as if' mode of dramatic action and reflect on that experience, converging as a group of storytellers that actively listen and respond to each other's imagination. As Edminston (1998) argues, students' ethical self is "born of the fundamental recognition of relatedness' that which connects me naturally to the other, reconnects me through the other to myself" (Noddings, 1984 in Edminston, p. 56). This stance on nurturing a student's 'ethical self' aligns with White and Lorenzi's (2016) definition of creative space in education: "A creative space should empower students to become autonomous agents who can think for themselves and have an analytical capacity which enables them to choose between alternative options while also considering the impact of those choices on others." (White \& Lorenzi, 2016, p. 785). We see trust and vulnerability as two fundamental aspects to enable this space. This kind of creative vulnerability, key to practitioners' ethical imagination in performative work, can act as the leeway into metaphorical level, characterised by a degree of aesthetic distancing (Bullough, 1912/2001; Eriksson, 2022). Yet, as Marschall notes:

Many meaningful socially engaged art works and theatre projects with and
about refugees have aimed to bring about individual empowerment, have
put up a fight for the rights of the marginalised and have created a new
sense of belonging within new cultural environments. However, sometimes
what becomes problematic in the ubiquity of the represented, aestheticised
refugee body is the prevalent disjuncture of we and them, of here and there.
(2018, p. 149)

In the Sorgente project, our intention is to create a metaphorical bridge that could connect these binaries through effective storytelling that taps into archetypal, universal values.

We opened the article with a poignant statement by Cañas (2015) who, in the RISE manifesto, urges artists to consider that "participation is not always progressive or empowering". We acknowledge that storytelling can be a double-edged sword - a sharp sword and one we must wield with care. As we stare at the blade, we wonder: How can performative language practice support an ethical imagination in the practitioners involved in the Sorgente study? This new research question opens up novel possibilities, as we consider the insights discussed in this paper in our future cycle of praxis. 
Piazzoli \& Kir Cullen: The double-edged sword of storytelling

Bibliography

Ardener, S. (1993). Ground rules and social maps for women: An introduction. In S. Ardener (Ed.), Women and space: ground rules and social maps (pp. 1-30). Berg.

https://doi.org/10.4324/9781003135081-1

Balfour, M., Bundy, P., Burton, B., Dunn, J., \& Woodrow, N. (2015). Applied theatre: Resettlement: Drama, refugees and resilience. Bloomsbury Publishing. https://doi.org/10.5040/9781472522993

Berman, R. A. (2018). Between alienation and identity: Toward a critical theory of refugees. Telos, 2018(183), 145-167. https://doi.org/10.3817/0618183145

Best, C., Guhlemann, K., \& Guitart, O. A. (2020). The social art of language acquisition: A theatre approach in language learning for migrants and its digitization in the Corona lockdown. Scenario, 14(2), 60-75. https://doi.org/10.33178/scenario.14.2.4

Bolton, G. (1979). Towards a theory of drama in education. Longman.

Bolton, G. (1984). Drama as education: An argument for placing drama at the centre of the curriculum. Longman.

Bora, S. F. (2019). Exploring learners' perceptions towards collaborative work through drama in foreign language learning: A view from a mandatory Italian high-school curriculum. Scenario, 13(2), 171-186. https://doi.org/10.33178/scenario.13.2.11

Bocconi, S., Kampylis P. G., \& Punie, Y. (2012). Innovating learning: Key elements for developing creative classrooms in Europe. JRC Scientific and Policy Reports, European Commission.

Boost Rom, R. (1998). "Safe spaces": reflections on an educational metaphor. Journal of Curriculum Studies, 30(4), 397-408. https://doi.org/10.1080/002202798183549

Bullough, E. (1912/2001). Psychical distance as a factor in art and an aesthetic principle. British journal of Psychology, 5(2), 87-118. https://doi.org/10.1111/i.2044-8295.1912.tb00057.x. SophiaOmni Project retrieved from www.sophiaproject.org/uploads/1/3/9/5/13955288/bullough psychicaldistance.pdf

Butler, J. (2014). Bodily Vulnerability, Coalitions, and Street Politics. Critical Studies, 37.

Cañas, T. (2015). 10 things you need to consider if you are an artist. http://riserefugee.org/10-thingsyou-need-to-consider-if-you-are-an-artist-not-of-the-refugee-and-asylum-seeker-communitylooking-to-work-with-our-community/ [accessed December 29yh, 2021]

Campbell, V., \& Hogan, Z. (2019). Pandora and the Tiger's Whisker: stories as a pretext in two adult language learning contexts. NJ, 43(1), 39-50. https://doi.org/10.1080/14452294.2019.1585931

Change of Address (n.d.). About. www.changeofaddresscollective.com/about

Courtney, R. (1995). Drama and feeling: An aesthetic theory. Montreal: McGill-Queen's University Press.

Cummings, L. (2016). Empathy as dialogue in theatre and performance. Macmillan. https://doi.org/10.1057/978-1-137-59326-9 
Piazzoli \& Kir Cullen: The double-edged sword of storytelling

Dalziel, F., \& Piazzoli, E. (2019). "It comes from you": Agency in adult asylum seekers' language learning through Process Drama. Language Learning in Higher Education, 9(1), 7-32. https://doi.org/10.1515/cercles-2019-0001

Davies, D., Jindal-Snape, D., Collier, C., \& Duigby, R. (2013). Creative learning environments in education-A systematic literature review. Thinking Skills and Creativity, 8, 80-91. https://doi.org/10.1016/j.tsc.2012.07.004

Dunn, J., Bundy, P., \& Stinson, M. (2015). Connection and Commitment: Exploring the Generation and Experience of Emotion in a Participatory Drama. International Journal of Education \& the Arts, 16(6).

Dunn, J., Bundy, P., \& Stinson, M. (2020). Process drama in five international contexts: Considering emotional responses and dramatic structuring. Applied Theatre Research, 8(2), 177-195. https://doi.org/10.1386/atr 000371

Dunn, J., Bundy, P., Jones, A., Stinson, M., Hassall, L., Penton, J., Lazaroo, N., \& Le, L. (2019). Creating Critical Connections through the Arts: Examining the impact of arts-based pedagogies and artist/teacher partnerships on learning and teaching in one Australian secondary school - the $Y$ Connect Report. Griffith Institute for Education Research. https://www.yconnectproject.com

Edmiston, B. (1998). Ethical imagination: Choosing an ethical self in drama. In JD Wilhelm \& B. Edmiston (Eds.), Imagining to learn: Inquiry, ethics, and integration through drama (pp. 55-84). Heinemann.

Eriksson, S. (2007). Distance and awareness of fiction: Exploring the concepts. NJ: Drama Australia Journal, 31(1), 5-22. https://doi.org/10.1080/14452294.2007.11649505

Eriksson, S. A. (2011). Distancing at close range: making strange devices in Dorothy Heathcote's process drama Teaching Political Awareness Through Drama. RiDE, 16(1), 101-123. https://doi.org/10.1080/13569783.2011.541613

Eriksson, S. (forthcoming, 2022). Distancing as Topos in process drama. In M. McAvoy \& P. O'Connor (Eds.), The Routledge Companion to Drama in Education. Routledge. Heinemann Drama.

Gilbert, H. \& Nield, S. (2008). Editorial. RiDE, 13(2): 133-136. https://doi.org/10.1080/13569780802074990

Hatton, C. (forthcoming, 2022). Drama as a pedagogy of connection: using Heathcote's rolling role system to activate the ethical imagination. In M. McAvoy \& P. O'Connor (Eds.), The Routledge companion to drama in education. Routledge.

Heathcote, D. \& Armstrong Mills, C. (1993). Rolling role and the national curriculum. (Video Tape series, 1-16). Audio Visual Centre, University of Newcastle Upon Tyne.

Hemelryk Donald, S. (2018). Debt, the migrant, and the refugee: Lampedusa on stage. Research in Drama Education: The Journal of Applied Theatre and Performance, 23(2), 193-209. https://doi.org/10.1080/13569783.2018.1438177 
Piazzoli \& Kir Cullen: The double-edged sword of storytelling

Hietz, K. (2021). (No) drama with grammar: A case study of a performative approach to teaching English conditional clauses to young adolescent learners. Scenario, 15(1), 128-135.

https://doi.org/10.33178/scenario.15.1.9

Hunter, M. A. (2008). Cultivating the art of safe space. RiDE, 13(1), 5-21.

https://doi.org/10.1080/13569780701825195

Jankowska, M., \& Atlay, M. (2008). Use of creative space in enhancing students' engagement. Innovations in Education and Teaching International, 45(3), 271-279.

https://doi.org/10.1080/14703290802176162

Jeffers, A. (2008). Dirty truth: Personal narrative, victimhood and participatory theatre work with people seeking asylum. RiDE, 13(2), 217-221. https://doi.org/10.1080/13569780802054919

Kenney, M. (2001). Mapping gay LA: The intersection of place and politics. Temple University Press.

Kenny, A. (2018). Voice of Ireland? Children and music within asylum seeker accommodation. Research Studies in Music Education, 40(2), 211-225.

https://doi.org/10.1177/1321103X18794197

Lamia, M.C. \& Krieger, M.J. (2009). The White Knight Syndrome: Rescuing yourself from your need to rescue others. New Harbinger Publications.

Marschall, A. (2018). What can theatre do about the refugee crisis? Enacting commitment and navigating complicity in performative interventions. RiDE, 23(2), 148-166.

https://doi.org/10.1080/13569783.2018.1438180

Piazzoli, E., \& Kennedy, C. (2014). Drama: Threat or opportunity? Managing the 'dual affect' in process drama. Scenario, 8(1), 52-68. https://doi.org/10.33178/scenario.8.1.5

Piazzoli, E. (2018). Embodying language in action: The artistry of process drama in second language education. Springer. https://doi.org/10.1007/978-3-319-77962-1

Price, T. (2018). Performing crisis: The COBRA committee and the aesthetics of governmental response. RiDE, 23(2), 167-178. https://doi.org/10.1080/13569783.2018.1439734

Redmond, M. (2010). Safe space oddity: Revisiting critical pedagogy. Journal of Teaching in Social Work, 30(1), 1-14. https://doi.org/10.1080/08841230903249729

Schewe, M. (2020). Performative in a nutshell. Scenario, 14(1), 103-110. https://doi.org/10.33178/scenario.14.1.7

Smith, A. (2016). Faith Action. Seven tips for starting work with refugees. http://www.faithaction.net/blog/2016/06/21/seven-tips-refugees/

Smith, A. (2016b). Creative English: Balancing creative and functional language needs for adult refugees, asylum seekers and migrants. Scenario, 10(1), 3-17.

https://doi.org/10.33178/scenario.10.1.1

Thompson, M. J. (2017). Introduction: What is critical theory? In M. J. Thompson (Ed.), The Palgrave Handbook of Critical Theory (pp. 1-14). Palgrave. https://doi.org/10.1057/978-1-137-55801-5 
Piazzoli \& Kir Cullen: The double-edged sword of storytelling

van Lier, L. (2007). Action-based teaching, autonomy and identity. Innovation in Language Teaching and Learning, 1(1), 46-65. https://doi.org/10.2167/illt42.0

White I. \& Lorenzi, F. (2016). The development of a model of creative space and its potential for transfer from non-formal to formal education. International Review of Education, 62(6), 771-790. https://doi.org/10.1007/s11159-016-9603-4

Wittgenstein, L. (1953/2010). Philosophical investigations. John Wiley \& Sons.

Acknowledgment

We would like to thank all participants of the study for their time, their insights and openness.

Funding

The project is funded through Irish Research Council (IRC) New Foundations and involved a university-community partnership between Trinity College Dublin, the School of Education and City of Dublin Education and Training Board (CDETB). 